\title{
Sri Lanka: Ethnic Conflict and Disintegration of a Third World Democracy
}

\author{
Robert Oberst, \\ Nebraska Wesleyan University
}

The continued violence between the Tamil and Sinhalese communities in Sri Lanka is threatening the existence of political stability and democracy in that country. As the violence has intensified since the election of the United National Party government in 1977, both sides to the dispute have solidified their demands and appear increasingly less likely to compromise with the other side. The crisis in

Sri Lanka has resulted in a general breakdown in communication and peaceful interaction between the two communities. As a result, a peaceful solution to the dispute is highly unlikely. Certain conditions have appeared which have escalated the conflict beyond its original constraints. These conditions include a hardening of the attitudes of both sides to the conflict, a split in the leadership of the minority community, the rise of the influence of radicals among the minority community, and a decline in the influence of the moderates.

Arend Lijphart has argued that stability in multiethnic states is dependent upon several prerequisites: (1) an ability to recognize the dangers inherent in a fragmented system; (2) a commitment to system maintenance; (3) an ability to transcend subcultural cleavage at the elite level; and (4) an ability to forge appropriate solutions for the demands of the subcultures. He believes that elite perceptions of the communal conflict are the crucial element in communal harmony.

Some of these conditions in Sri Lanka are not being met. Both sides agree that there is a danger in the conflict between them. Further, both groups are committed to maintaining the system. Both sides also appear to have been able, in the past, to communicate and interact in order to break down the subcultural differences. The fourth condition has not been met. The two sides have not been able to forge appropriate solutions to the demands of the Tamil subculture. Since independence, there have been a series of policies passed by the national government which have established the majority ethnic community in a position of dominance. The failure to meet this condition has led to a deterioration in meeting the other prerequisites for stability.

The result has been a hardening of attitudes by both sides in the conflict with a consequent lower commitment towards system maintenance. A split in the minority group leadership has allowed more radical elements to gain control of the minority group leadership. These more radical groups are less committed to the maintenance of the system. In addition, an increased level of violence has resulted as the two major ethnic groups fail to see the dangers inherent in a non-negotiated solution to the conflict. It would appear that both sides see violence as a better means to solving the conflict than negotiation.

There is a great deal of ethnic diversity in Sri Lanka (Box I). However, the communal conflict on the island is centred on two of the many ethnic communities - the Sinhalese and Tamils. The political system is dominated by the Sinhalese community.

The Sinhalese speak an Indo-aryan language, Sinhala, and consider themselves the original civilized inhabitants of the island. They are mostly Buddhist and feel threatened by the large Dravidian Hindu culture to the north of the island in India. The Tamils on the island are divided between the Indian and Ceylon Tamils. The Ceylon Tamils trace their ancestry to invaders from South India who arrived on the island around the same time as the Sinhalese. They comprise 12.6 percent of the island's population and are concentrated in the northern and eastern sections of the island. Most Tamils practice Hinduism and speak a Dravidian language.

The Indian Tamils are descended from estate workers brought from South India to Sri Lanka in the late nineteenth and early twentieth century to care for the tea and coffee estates. They were stripped of their citizenship shortly after independence. Many Indian Tamils either have been sent back to India or given Sri Lankan citizenship. However, around 200,000 remain stateless or await return to India. In addition to these groups, there are several other ethnic groups on the island. Of these only the Moors are of importance to this study. The Moors are found predominately on the eastern coast and in major trading towns along the western coast and in the hill country. Most speak Tamil and therefore the Ceylon Tamils have sought, apparently unsuccessfully, to enlist their support in their conflict with the Sinhalese.

The conflict between the Tamils and the Sinhalese dates back to precolonial times. However, the independence era has been marked by several sharp conflicts between the two groups. After independence tension developed over the status of the Indian Tamils. In the 1947 elections, six Indian Tamils were elected to Parliament under their own party label, the Ceylon Indian Congress. In 1948, the Indian Tamils were stripped of their citizenship and denied the right to vote in future elections. This was justified by the argument that the Indian Tamils did not owe their allegiance to Sri Lanka but rather to India and therefore should not be allowed to have influence in Sri Lankan politics. The election of S.W.R.D. Bandaranaike's Mahajana Eksath Peramuna in 1956 led to a heightening of tension as the new leadership began to make Sinhala the language of government. In May 1958, serious 
communal rioting swept the country. The 1960s and early 1970s were marked by further negotiations between the leaders of the two communities over the role and influence of the Sri Lanka Tamil community. In the 1970s, the Tamil leadership sharpened their demands. This was followed by a series of communal riots starting after the elections of 1977, and followed in August 1981 and July 1983.

These outbreaks of violence were largely ignored by the outside world until the riots of July 1983 . The government has listed the death toll in this violence at 387 killed (Government of Sri Lanka, n.d.). Unofficial estimates of the numbers killed run considerably higher. Again in 1984, the conflict reached the western news media. In April, government forces went on a rampage against Tamils in the north after a bomb was thrown at an army truck. Estimates of the dead range up to 234 killed. In April, a United States AID worker and his wife were kidnapped by a group of Tamil youths. Both were set free and unharmed but the incident received a great deal of press coverage in the United States media.

This violence is set in the context of a nation of approximately 15 million people. From 1948 to 1978, the island was governed by a Westminster-style government. It established itself as one of the most competitive and open democracies in the world with successive governments losing their bids for reelection in 1956, March 1960, July 1960, 1965, 1970, and 1977. In 1978, the government of Prime Minister J.R. Jayawardene and his United National Party changed the Westminster parliamentary system to a system based on the French model of government. Jayawardene was named the first executive President and given powers which exceeded those held by the former Prime Ministers. Since 1977, the communal situation has deteriorated.

\section{The Hardening of the Demands of the Tamil Leadership}

The Tamil leadership's position towards the government and the
Sinhalese parties is based on a longstanding refusal to accept the constitutional structure of Sri Lanka and to search for greater autonomy and home rule. They refused to participate in the deliberations over the constitutions of 1972 and 1978, based on a desire to gain a certain degree of autonomy over the regions of the island in which they predominate or traditionally have predominated. Under the present constitutional arrangement, the Tamils can never hope to have an important part in decision making. Thus, they seek a situation where a certain amount of power will always be guaranteed to them in a federation similar to what they regard the situation at the time of the coming of the British. They have refused to accept the sovereignty of the Sinhalese and consider themselves part of the federated states of Ceylon.

The search for autonomy has been fueled by several concerns. The first has been the language issue. As long as the British ruled Ceylon, an alien language, English, was imposed upon them as the language of government. No serious problems arose as long a the British ruled the country. As soon as the British left the country, the issue emerged as an important point of confrontation. The official Language Act of 1956 named Sinhala as the one official language of Sri Lanka. This began a series of compromises and negotiations between the two communities. The Constitution of 1978 gave the Tamil language special status in some government dealing but maintained the superiority of Sinhala in the society. The naming of Tamil as a "National Language" while Sinhala remains the one "Official Language" did not satisfy the Tamil leadership and the problem remains a point of confrontation.

The second concern has been the employment and education issue. In both of these areas, youths have been the main people affected by the government policies. The Tamils have claimed that they are not receiving a fair share of government jobs. The government sector is the main source of high status jobs in the society. As Sinhala has become more important as the language of govern- ment, the Tamils have become mor concerned with their access to government employment. Admis sions to universities have also raised similar questions. Prior to 1970 admissions were based on final examination results at grade XII. In 1970, the United Front government of Sirimavo Bandaranaike became concerned with the better perfor mance of Tamil students in the exam inations. This was especially the case in the natural science exams. This concern led to a series of attempts to provide affirmative action for the Sinhalese students. A system of stan dardization was initially tried. Ultmately quotas were established for each community and university entrance exams became an issue of dispute. Despite changes by the Jayawardene government, the issue? remained a point of confrontation.

A third concern has been the Sinhalese colonization of traditional Tamil areas. In Trincomalee, Vavuniya, and Batticaloa districts, recently irrigated lands have been opened for settlement. In many areas, especially in Trincomalee, the lands have been given to Sinhalese settlers. This has had the effect of reducing the Tamil percentage of the population in these areas. The problem has been amplified by the Mahaweli Development Project? which is now opening up new lands at a very rapid rate. In Trincomalee alone, the number of Sinhalese has increased sharply enough that Tamil plurality in the district is threatened.

A fourth concern has been regional autonomy or control over three significant policy areas directly affect? ing the Tamils.

The first issue is the number and level of development projects in Tamil areas. The Tamils feel that the have not received a fair share of the projects available. Thus, they are los: ing out on the income and jobs gen erated by such projects. Majo development efforts such as the Mahaveli river diversion plan and the Free Trade Zone at Katunayake are both located in predominantly Sinhalese areas and largely benefit Sinhalese citizens.

The second issue has been the maintenance of law and order. 
many years the majority of the police and armed forces in the Tamil areas were Sinhalese. Recent changes have led to a reduction of Sinhalese police and an increase in the number of Tamil police. This has not satisfied the Tamils, and many of the guerilla attacks have been directed at the Sinhalese police and soldiers.

Accompanying this problem has been the lack of control that the officer corps of the armed services exert over their subordinates. On several occasions since 1977, the - armed forces in the Tamil areas have gone on rampages against the Tamils. In these incidents, innocent divilians have been attacked. there have been widespread reports that during the riots of 1983 , police and army units attacked Tamils or refused to defend them when they were attacked by rioters. In the spring and summer of 1984, the number of these incidents increased sharply with widespread attacks in the Tamil areas. In April and August several hundred people appear to have been killed as the police and soldiers randomly retaliated against Tamils for actions taken against them by the Tigers.

A third issue has been the devolution of power to the Tamil areas. Early calls for a federal system in Sri Lanka acknowledged the Tamil's desire for $\checkmark$ limited autonomy. Although the government has supported the concept of decentralization in principle, recent attempts at decentralization such as the decentralized budget and the District Development Councils have failed to meet the demands for autonomy or to transfer very much power to the Tamil areas.

These four concerns have led the Tamil leadership to make their demands for an independent state of Tamil Eelam. These demands for Eelam reversed a policy that originated in the early 1950 s calling for a federal system. On May 14, 1976 the Tamil leadership held a convention in Vaddukoddai, on the Jaffna peninsula. At this meeting, attended by most factions of the Tamil community, the leadership announced their intention to seek a separate, free and sovereign state of Tamil Eelam in the northern and eastern portions of the country.

The issue of Eelam I addressed in a series of interviews conducted in 1979 and after. Although the evidence is highly impressionistic, it would appear that most TULF leaders were using Eelam as a bargaining tool. Their goal was to use it to achieve some form of a federal system in Sri Lanka. With the exception of a few former TULF Members of Parliament, this appeared to be true. When questioned about the viability of an independent state of Eelam several even indicated that the Tamil country could not survive. Others when pressed, indicated that a federal solution might still work in Sri Lanka. Thus, it appeared that the demands for an independent state were little more than part of a bargaining plan.

Since 1979, the violence has intensified and reached levels which had been considered unheard of before. It would appear that the TULF leadership's attitudes toward the creation of Eelam have stiffened. Several of the former Tamil MPs have now expressed the belief that the Tamil people can never live in the same political state as the Sinhalese in the future. However, it would appear that a solution guaranteeing the safety of the Tamils and providing for economic development in the Tamil areas would be acceptable to the TULF leadership. However, the more radical Tiger organizations might not find such a solution acceptable. With the increased levels of violence have also come a radicalization among the Tamil youths. The TULF has increasingly failed to respond to their demands. In early 1984, the TULF agreed to join in the All Party Conference sponsored by the government. Significant elements of the Tamil youths opposed this action.

The continuing provocations by both sides have made a compromise very difficult. Each new hostility has widened the gap between the communities. Since the riots of August 1983 , it would appear that there is some sentiment among the Tamil leadership that no compromise can come as long as President Jayawardene remains in power. He and his government appear to have lost credibility in their dealings with the Tamils. Jayawardene's behaviour during the riots of 1983 has alienated many Tamils. He is accused of not taking action quickly enough. In the early stages of the rioting (which was directed at Tamils) he remained silent. When he finally did respond with a televised address, many Tamils felt that he was not forceful enough in condemning the violence against the Tamils. These actions coupled with the activities of his government and the people in it have increased the Tamil doubts. There is ample evidence that the Minister of Industry and Scientific Affairs at that time, Cyril Mathew, was implicated in some of the mob attacks against the Tamils. In addition, the excesses or lack of assistance from the army, police and prison guards when Tamils were attacked during the riots has added to Tamil fears. Many policemen were accused of standing by and watching the rioters attack Tamils. Police and army abuses in the past have been treated very leniently by government authorities.

At the same time as the Tamils were losing faith in Jayawardene's sincerity in dealing with the crisis, the TULF was losing its position as the spokesmen of the Tamils. The TULF has steadfastly supported a nonviolent approach to the conflict. As the position of the Tamils has eroded since 1977, the government has taken a harder line toward the Tamils and increased certain activities which the Tamils have opposed. These activities include, the police and army abuses mentioned earlier, increased surveillance and searches in the north and the policies of colonization mentioned earlier. The most important blow to the TULF has been the stripping of their parliamentary seats in October 1983. This removed them from their one position of power in the political system. They lost their forum to challenge the government and their legitimacy as the leaders of the Tamils. Tamil youths have found it increasingly harder to accept a peaceful approach towards the Sinhalese when they are denied access to the government through their legitimate elected representatives. 


\section{The Decline of the Tamil Moderates and Rise of the Radicals}

There appears to be a major division within the leadership of the Tamil community. The division is not between organized political parties, but between the politically dominant Tamil United Liberation Front (TULF) and several guerilla organizations commonly referred to as the Tigers. These two groups differ in several important respects. In the case of the TULF, we find a legal political party which, until its members refused to take a loyalty oath after the riots of 1983, was represented in parliament. At the present time, the party is the only viable political party in the areas of the country dominated by the Sri Lanka Tamils.

The Tigers include several outlawed guerilla organizations consisting primarily of young people who have grown increasingly dissatisfied with their position in Sri Lankan life and society. They have resorted to violent means to make their case known. There have been several estimates of the number of Tiger organizations ranging from a low of five to a high of 11. Many of them are ad hoc groups centred around one individual. No matter how many groups there may be, only a few of the groups have extensive influence. The two most influential groups include the People's Liberation Organization of Tamil Eelam (PLOTE) which is led by Uma Maheshwaran, and the Liberation Tigers of Tamil Eelam (LTTE) led by Velupillai Prabhakaran. Both of these organizations have a significant membership, ranging from 1,000 to 5,000 armed followers.

There appears to be a generation and caste gap between the TULF and the Tiger groups. The TULF leadership is dominated by older men who are members of the high status Vellala (cultivator) caste. For the most part, the TULF leadership has been involved in politics since the 1950s and 1960s. They are part of a generation who tried the politics of accommodation in the years shortly after independence. It was in these years that Tamil rights were slowly eroded with the disenfranchisement of
Indian Tamil citizenship, and the government language policy of the 1950s.

The Tigers, on the other hand, are made up of much younger people, and some groups of them are dominated by castes other than the Vellala, such as the Karaiyar (fisher) caste. They are part of the post-war generation which is suffering from the same economic conditions as the Sinhalese youths of this generation. High unemployment coupled with high levels of educational attainment have led to deep-seated dissatisfaction with the political system. In 1972 , a violent youth-led insurrection took place that consisted largely of Sinhalese youths with only limited Tamil involvement. In some ways, the Tiger movement may be viewed as a delayed reaction to the same conditions which led to the 1972 insurrection.

In the late 1970s, there appeared to be close ties between some of the TULF leaders and the Tigers. Increasingly, the link between the TULF and the Tigers appears to have weakened, although some communication still exists between Prabakaran's LTTE and the TULF. The youths have become more frustrated with the failure of their methods, and the inability of the TULF leadership to work out an acceptable compromise. Thus, the Tigers appear to have taken a more independent path in their recent actions and are no longer as closely linked to the TULF.

The dissatisfaction between the TULF and the youths has expressed itself in several ways. Tamil youths openly challenged the TULF call for a satyagraha (non-violent protest) in the north to mark the first anniversary of the July 1983 riots. Shortly after this, small bombs were thrown at the train which was to carry several TULF leaders to Colombo to participate in the Round Table Conference called to resolve the conflict. It should be noted that no violent actions have been taken directly against the TULF leadership as occurred to former Tamil Congress and UNP Tamil leaders. Jaffna Mayor Alfred Durriayappah, an independent, and former Tamil Congress MP, A. Tiagarajah were both assassinated by the guerillas. Several other politis have been attacked and seris injured or killed by the youths. Despite the division in the 1 it leadership, the TULF appears to widespread support in the peninsula. No other politicalis has been able to challenge its nance since the early 1970 s. This? port has continued to throughout the violence and certed attempts by the Uni. National Party government to gai political foothold among the Tain. people. After the Tamil leadens. refused to cooperate with development of a new constitution the UNP embarked on a polic gain electoral support in the regio This policy was a failure with exception of two parliamentate defections of TULF MPs to th government. The electorate as whole appeared to remain behind th TULF leadership.

In the presidential elections of 1982 the TULF called for a boycott of the elections while the All-Ceylon Tamil Congress (ACTC) ran a candidate of their own opposed to the incumbent President Junius Richard Jayawas dene. In Jaffna district, the strong hold and centre of TULF support, the UNP candidate Jayawardent. received the votes of only 9.1 percen of the total voters while 53.7 percent of the voters did not vote. In the 1977 parliamentary general elections, ont 28.5 percent of the electorate in Jaffin district failed to vote. The ACTC cant didate polled 17.7 percent of the tota votes. In other districts with high concentrations of Sri Lanka Tamils the UNP did better but their suppor was not impressive. Along the east coast of the island, few people boy cotted the election, but many voted for the ACTC. The UNP percentage of the total vote exceeded that of all other parties but fell short of a majos ity. In Batticaloa district, for instance they received only 27.9 percent of the vote. Even if the Tamils of the easteri coast did not support the TULF and its call for separation, they did nol appear to offer much support to the government or the other Sinhalese political party, the Sri Lanka Freedom Party (SLFP).

Since the failure of the UNP electoral strategy in the north, the UNP has 
attempted to undermine the credibility and support of the TULF. In August of 1983 the Sixth Amendment to the Constitution was passed and required that all Members of Parliament recite a loyalty oath which disavowed separatism. The TULF MPs refused to state the oath and were removed from parliament. This was followed by a government publicity campaign stressing the weakness and unrepresentativeness of the TULF. The TULF was left with no legitimate forum, such as parliament, to state their case, and as a result, their influence in the north appear to have declined while that of the Tiger appears to have increased.

Increasingly, the government has stressed that it is now dealing with the radical Tigers. These appeals have been used to influence public opinion in nations the government hopes to receive aid from, and to influence international public opinion.

\section{The Growth of Violence and the Breakdown of Communication}

The summer of 1984 marked a watershed in the communal problem. The government and the Tigers amplified their violent actions while the centre of Tamil power and influence shifted towards the Tigers. Tiger attacks during the summer of 1984 occurred almost daily. These attacks were followed by a change in government tactics. The government enlisted the aid of Israel to train and assist them in antiterrorist activities, while also hiring a British-based private commando team to help. In August of 1984, the United States Navy began to help with surveillance of the seas between India and Sri Lanka. The Sri Lankan military has taken a much harder line toward the villages where attacks occur. In the past when the Tigers attacked, bystanders would claim to have seen nothing when the authorities arrived. It appears that the army is now punishing villages where resistance exists. In August, two attacks in different areas of the north led to military retaliations. On August 4, Tamil guerillas killed two sailors. In retaliation, security forces rounded up about 680 youths in the village and took them away. The next day the village was bombarded - villagers claiming it was a naval bombardment while the government claiming it came from land-based cannons. In the other case, over 3,000 people were left homeless and a large number of shops were destroyed in the city of Mannar as soldiers once again retaliated for an attack against them.

Along with the increased violence came a breakdown in the communication between the two communities. The All Parties Conference (Round Table Conference) which had been meeting for nearly a year, presented a series of proposals in December, 1984. All of the major opposition parties including the TULF rejected the proposals. The conference ended in failure with the government vowing not to negotiate with the TULF again unless they dropped their demands for Eelam. The breakdown in communication and the escalation of the violence further limits the possibility of a peaceful resolution of the conflict.

The animosity of the two communities is fueled not only by the violence against each other, but also by a series of socio-economic events which have affected the country as a whole. Much of the antagonism between the two communities is the result of factors beyond the control of both parties, or part of the general accepted way of doing things politically in the country. These factors are the frustration created by the baby and education boom of the 1950s and 1960s, the patronage system, and the Sri Lankan system of distributing development projects.

In both the Sinhalese and the Tamil areas of the country there are too few jobs for the educational qualifications of the people seeking them. This is, in large part, a consequence of the baby boom of th 1950s and 1960s, and the growth of the educational system which also occurred during this time. The growth of the educational system allowed large number of young people to receive secondary and university degrees. The increased educational opportunities expanded the expectations of the young people with their careers. The economic sys- tem could not keep pace with the expansion of the educational system by providing jobs for them commensurate with their educational attainment. Thus, many of the educated youths became underemployed or unemployed. It has been argued that this situation has led to a great deal of frustration among youths and that this was one cause of the insurrection of Sinhalese youths in 1972. The same factors affected the Tamil youths although, for the most part, they did not become involved in the 1972 uprising.

However, for the Tamil youths, several other ingredients added to the situation. The imposition of quotas for university admittance came at a poor time - in the early 1970s. This heightened the sense of frustration at a time when jobs were becoming even scarcer. In addition, the increasing requirements for Sinhala proficiency limited the number of government jobs available. Finally a more serious problem also added to their sense of frustration. Sri Lankan politics is marked by high levels of patronage - patronage in jobs and in the placement of development projects. Because the Tamils have persisted in electing representatives to parliament from their own Tamil parties and not from the Sinhalese dominated parties which have controlled the governments of Sri Lanka, they have not received the benefits of patronage. Thus, the growth of educational opportunities and the large numbers of baby boom youths entering the job market have led to increased frustration which in turn fueled Tamil dissatisfaction and violence. These frustrations have been exacerbated by the patronage system of Sri Lankan politics funnelled through representatives of the governing party.

The patronage system is not inherently biased against the Tamils but biased against any electorates which consistently returns Members of Parliament who are not members of the governing party. Unfortunately, the only areas of the island to do this are the Tamil areas.

Another of the inherent systemic biases against the Tamils is the placement of development projects. Development projects are also part of 
the patronage system. Projects are more likely to be placed in electorates controlled by the government party than they are in electorates controlled by opposition party members. This is true whether the projects are set up directly by the ministries involved or through the decentralized budget.

\section{The Future of the Tamil Crisis in Sri Lanka}

The arguments spelled out in the earlier passages of this analysis present a very pessimistic view of the future of the political stability of Sri Lanka. The final section of this paper will not change this view. The Sri Lanka ethnic communities have reached a stage of crisis in which communication between the communities has broken down and where each community has lost its trust in the other side. The necessary prerequisites for consociational democracy that at one time existed have disappeared. Thus, both sides are unwilling to compromise. The government finds itself in a position of power with widespread support from the Sinhalese commun- ity and a President who believes that he has done all that he can to reach a compromise. The Tamil leadership is split between radicals and moderates who do not trust the sincerity of the current government leadership specifically President Jayawardene.

One can not reasonably expect the Tamil leadership to change their distrust of the Sinhalese government without major concessions. Major concessions include the establishment of some form of home rule or autonomy. Each new act of violence has reinforced the attitudes of the Tamil leadership. Not only do they fear being governed by the Sinhalese, but the present leadership of the TULF have lost much of their credibility. The emergence of the radical leadership as a spokesperson for the Tamils has further complicated the crisis. The government has effectively undermined the moderate leadership and now must deal with the radicals. This makes it much more likely that a solution will not be found until the present leadership in Colombo is changed or the Tamil people are forcibly subdued. A government or major shift in pot positions will allow the moderate? reassert their position of leadersh? among the Tamils. A further comp cation is the systemic bias built ind the political structure. The patrona system and its favouritism towand the government-controlled are (Sinhalese areas) will further alien Tamil young people. The compliance and involvement of the Tamil youthe in a solution is absolutely necessary. Thus, their frustration must be reduced. This will require several major changes in the way government benefits are handled in Sid Lanka. Government employment must be determined on the basis of merit rather than influence. Development projects must be placed on the basis of economic merit rather than political clout.

In the final analysis, the possibility of a peaceful settlement lies in the hands of the government. At the present time, the government does not appear to be committed to the necessary policies and attitude required for a peaceful solution.

BOX 1

\section{ETHNIC POPULATION OF SRI LANKA}

\begin{tabular}{|c|c|c|}
\hline Ethnic & Number & $\begin{array}{l}\text { Percent of } \\
\text { Population }\end{array}$ \\
\hline Sinhalese & $10,985,666$ & 74.0 \\
\hline Ceylon Tamils & $1,871,535$ & 12.6 \\
\hline Ceylon Moors & $1,056,972$ & 7.1 \\
\hline Indian Tamils & 825,233 & 5.6 \\
\hline Malays & 43,378 & .3 \\
\hline Burghers & 38,236 & .3 \\
\hline Others & 28,981 & .1 \\
\hline
\end{tabular}

SOURCE: $\quad$ Statistical Abstract of the Democratic Socialist

Republic of Sri Lanka, p. 32, 1982 (Colombo:

Department of Census and Statistics, 1982). 